\title{
DISCURSIVE STRUGGLES OVER THE TURKISH AGRICULTURAL COOPERATIVE FIELD: LIBERAL VS ETATIST FRAMES DURING THE EARLY REPUBLICAN ERA, 1930-1933
}

\author{
DOI: 10.17261/Pressacademia.2020.1183 \\ RJBM-V.7-ISS.1-2020(1)-p.1-12
}

\section{Cemil Ozan Soydemir ${ }^{1}$, Mehmet Ercek ${ }^{2}$}

${ }^{1}$ Istanbul Technical University, Management Engineering, Istanbul, Turkey. soydemirc@itu.edu.tr, ORCID: 0000-0001-6671-8873

${ }^{2}$ Istanbul Technical University, Management Engineering, Istanbul, Turkey. ercekme@itu.edu.tr, ORCID: 0000-0002-5212-7121

Date Received: January 4, 2020

Date Accepted: March 3, 2020

To cite this document

Soydemir, C.O., Ercek, M., (2020). Discursive struggles over the Turkish agricultural cooperative field: liberal vs etatist frames during the early republican era, 1930-1933. Research Journal of Business and Management (RJBM), V.7(1), p.1-12.

Permemant link to this document: http://doi.org/10.17261/Pressacademia.2020.1183

Copyright: Published by PressAcademia and limited licenced re-use rights only.

\section{ABSTRACT}

Purpose - This study aims to solve a historical puzzle in Turkish cooperative history and illuminate the failure of a discursive medium, the journal of Türk Kooperatifçisi, to realize its ambitious goals of disseminating liberal ideas into the field of agricultural cooperatives. Given the strong state influence on Turkish cooperatives for over a century, this article strives to articulate when and how the anti-etatist cooperative discourse experienced an absolute defeat in the face of state hegemony.

Methodology - This historical case study carries out hermeneutical discourse analysis on the archival data collected from the National Library of Turkey. Drawing on the first Turkish cooperative periodical, namely the Türk Kooperatifçisi, the researchers have read 214 articles, amounting to 966 pages. After a systematic interpretation of the collected data, the researchers have further situated archival evidence onto a plot and accordingly constructed a historical narrative, thereby illuminating the underlying reasons for the short life span (1930-1933) of a liberal cooperative periodical in early Republican Turkey.

Findings- The findings of this study suggest that towards the end of the 1920s, the sharp turn in the economic policy of Turkey triggered a series of events, leading the agricultural cooperatives to become state apparatuses. Correspondingly, the liberal frame regressed in the face of the etatist frame and became defeated in the discursive arena.

Conclusion- The contest between frames both shapes and becomes shaped by the ideological shift in the Turkish state polity. However, this macro-level change yielded in the Turkish agricultural-cooperative field an open forum where opposing discourses challenge for the settlement of expedient cooperatives.

Keywords: Framing, agricultural cooperative, discourse, organizational form, Turkey, Etatism JEL Codes: P13, N85, N95

\section{INTRODUCTION}

Cooperatives have long constituted an integral part of the Western economies as antidotes to the emerging capitalist system in history (Schneiberg, 2013), afflicting the labor force (Murphy, 1946), peasantry (Fairbairn, 2017; Guinnane, 1997), and artisans (Aschhoff, 1982). Initiated first by the laid-off 'Rochdale Pioneers' in the 1840s UK, the cooperative movement spread rapidly across the $19^{\text {th }}$ century Continental Europe. Following the fast-paced diffusion, however, the idea of cooperatives, without exception, became transplanted into different European countries as differentiated versions of the Rochdale cooperatives (Trampusch and Spies, 2014). Despite variations in their interpretation in various contexts, cooperatives historically refrained from extreme state intervention to their internal affairs. Even in such a state-corporatist country like Germany (Jepperson, 2002), the cooperatives accomplished to resist against the state domination almost a half-century. When eventually they became financially in need of the state-help before the turn of the $20^{\text {th }}$ century, the German cooperatives would urgently seek ways to liberate themselves from this dependency (Farr, 2007; Guinnane, 2012). 
On the other hand, historical records show that Turkish cooperatives display a stark contrast with their European counterparts in terms of their relations with and expectations from the state. The relationship between the Turkish state and cooperatives started with the first launch of the Ottoman Memleket Sandiks, a pseudo-cooperative form, in 1863 by an omnipotent statesman of his times, Midhat Pasha (Erçek and Soydemir, 2017). However, as time elapsed, these organizations gradually turned into state apparatuses, and finally, they became the offshoots of the state-owned Ziraat Bank in 1888 (Hazar, 1990). Given the traditionally pivotal role of the state in Turkish socio-economic life (Buğra, 1994; Genç, 2000), not surprisingly, the state-involvement would disguise itself under the cover of the state guidance and financial aids in the early Republican era to implement the ideological agenda of the state (Soydemir and Erçek, 2019).

As opposed to the general view, however, in the early Republican era, there was a contradictory discursive effort to settle liberal cooperatives in Turkey, alerting cooperative constituents for the danger of the state hegemony emerging at the horizon. Conveyed by the journal of Türk Kooperatifçisi, these liberal ideals vied for the settlement of modern cooperatives aligned with the Rochdale principles in the discursive arena. The discourse producers avowed the drawbacks of the extreme state intervention and warn cooperatives to stay aloof from custodian claims by the prevalent state bureaucracy. These voices, however, were silenced in the face of the rising discursive trend of etatism.

In light of this historical course of events, this study aims to illuminate the discursive struggle carried out during the early 1930 s. By doing so, it strives not only to demonstrate the interplay between competing discourses over the normative ground of the Turkish cooperatives but also to disentangle the underlying causes of the defeat of the liberal discourse. Moreover, the study shows how communication media shape the audience's cognition, employing framing tactics hidden in texts. Finally, it contributes to the framing literature by showing how the shift in state polity turns the scale for its subservient etatist discourse and defeats contradictory discourse once and for all.

Accordingly, the remainder of this study makes a literature review on cooperatives as an organizational form, framing as a distinct way of discursive effort, and finally, the economic context of Turkey in the post-Great Depression. In what follows, it introduces the methodology section, including the processes of hermeneutical discourse analysis and data collection. In the next section, the study narrates the discursive debate over etatism versus liberalism conveyed through the journal of Türk Kooperatifçisi. In the aftermath, the study proceeds with the discussion section in which the authors elaborate on their findings. Finally, the study wraps up with the conclusion section.

\section{LITERATURE REVIEW}

Drawing on social constructionism, some organizational scholars view language as the primary ontological entity for constituting social reality and advocate that the production and dissemination of texts mediate the construction of organizational phenomena, including organizational forms (Phillips and Oswick, 2012, p. 438). Given its organic relationship with the language, the discourse turns into a particular way of manifesting the physical and social world (Fairclough, 2005). Relatedly, the texts become an essential component of this representation. Addressing this connection, Grant and his colleagues (2004, p. 3) define organizational discourse as "... a structured collection of texts embodied in the practices of talking and writing (as well as a wide array of visual representations and cultural artifacts) that bring organizationally related objects into being as these texts are produced, disseminated, and consumed."

Equally importantly, scholars also heed attention to the possible researcher overemphasis on texts at the expense of overlooking the context, which in turn may lead to misguiding inferences about focal organizational phenomena (Gopinath and Prasad, 2012; Prasad and Mir, 2002). The elaboration on the context forestalls the probable interpreter alienation to the text and portrays the temporal, cultural, and social environment where the text production takes place (Kipping, Wadhwani and Bucheli, 2014, p. 325). In a nutshell, the context introduction is compulsory because the social construction of reality through discourse is a reciprocal process between the context and the text production (Fairclough, 1989, 2005). Thus, given the fact that discourse cannot be produced in a vacuum, it is equally important to take into account the socio-historical context that spawns the production and dissemination of the discourse.

Taken together, this section at the outset dwells on the concept of cooperatives as they distinguish from other economic forms of organization in terms of their raison d'être. In what follows, the section concentrates on a specific discursive mechanism, that is framing, as it targets at shaping the cognition of the text audience to facilitate the institutionalization of a given entity. Finally, the section concludes with the socio-economic context of Turkey in the pertinent temporal bracket to get a better understanding of why the liberal discourse waned in the case of agricultural cooperatives as of 1929. 


\subsection{Cooperatives as an Organizational Form}

Organizational form refers to the configuration of goals, practices, and identity, legitimacy claims of which depends on both its distinctiveness in the eye of the audience and appropriateness to the institutional context (Tracey, Dalpiaz, and Phillips, 2018). Its emergence is associated with a "...novel recombination of core organizational features involving goals, authority relations (including organization structure and governance arrangements), technologies, and client markets" (Rao and Singh, 2001, p. 244). Built on these dimensions, yet, differentiated from generic types of economic organizations, cooperatives have historically cropped up as suis-generis organizational forms, nevertheless, displayed variations among themselves according to their sociohistorical contexts (McLaughlin and Sharp, 2019).

Delivering its liberal notions from the Rochdale labor movement in the 1840s (Murphy, 1946) and perpetuating their core values since then (International Co-operative Alliance, 2019), cooperatives amalgamate a different and idiosyncratic set of principles, emphasizing the community interests over competitive motives. By definition, a cooperative is "... an autonomous association of persons united voluntarily to meet their common economic, social, and cultural needs and aspirations through a jointly-owned and democratically-controlled enterprise." Cooperatives go hand in hand with democracy and commit themselves, from the very outset of their foundation to their community-specific organizational goal. They embrace both the practices of self-help, cooperation, and self-responsibility and the ideals of democracy, equality, equity, and solidarity (International Co-operative Alliance, 2019). Drawing the boundaries of and describing the practices within the organizational form, the definition mentioned above brings the question of how this configuration becomes constituted on a normative ground under the surveillance of an attentive audience. Addressing this question, some scholars associate this legitimacy-building process to the resolute efforts of framing conveyed through communication media (Cornelissen and Werner, 2014; Werner and Cornelissen, 2014).

\subsection{Framing}

Frames are "principles of organization which govern social events and our subjective involvement in them" (Goffman, 1974, pp. 10-11). Goffman diligently describes them as the schemata of interpretation (ibid. 21) that provides the audience with a versatile tool to make sense of and give meaning to social action. The Spanish flu disaster between 1918 and 1919 in Norway epitomizes as to how frames prove functional at shaping the individual cognition. Rao and Greve (2017) convincingly elaborate on the way the community had framed the plague caused a severe decline in the founding rates of retail cooperatives both in the short and long terms. Put simply, the survivors framed the disease as a human-induced catastrophe rather than a natural incident. By doing so, they tended to distrust in others, which, in turn, led to a steep decline in the founding rates of cooperatives.

Frame sponsors use symbols and language in a context for either underpinning prevalent interpretive schemata or introducing new ones (Cornelissen and Werner, 2014). Generally, as a process-oriented mechanism, framing is attributed to political action or social movement where negotiation and mediation yield conventional means-end frames or field-level frames (Leibel, Hallett, and Bechky, 2018). This communicative action aims to persuade or dissuade the target audience to mobilize further support for and grant excessive legitimacy to (Cornelissen and Werner, 2014) an innovation (Hargadon and Douglas, 2001), a market category (Navis and Glynn, 2010), an organizational form (Rao, 1998), or a practice (Gurses and Ozcan, 2015).

At the field level, framing efforts restore a balance between the institutional orders that shape the behavioral patterns of organizations and individuals (York, Hargrave, and Pacheco, 2016). Moreover, institutional change in a given field may ensue the efforts of actors to constitute and sustain their distinctive identity. Case in point, Kyratsis et al. (2017) have shown that physicians in five transition European countries differentiate their identities from low-status professions in the aftermath of such a change. Apart from the professional identity, the settlement of new initiatives begs for further recognition in the eyes of the beholders. For instance, in their historical anecdote, Hargadon and Douglas (2001) narrated how Edison framed the new system of electrical lighting similar to the incumbent system of gaslighting in terms of its differential features while introducing the electric system in New York for the first time. Similarly, in the case of cable operators' entrance into the US TV broadcasting field, entrepreneurs had to introduce an original frame, as of the late 1950s, alternative to that of over-the-air pay-tv services. They have carried out this framing by presenting pay cable-tv as the state-of-the-art technology to the target audience to change the standards of the field (Gurses and Ozcan, 2015).

However, framing efforts are not immune to challenges. The literature shows that organizations and institutional fields are rife with frames, which usually compete in the form of negotiation during framing (Leibel, Hallett, and Bechky, 2018). Gilbert (2006) has found that in a newspaper publishing organization, the competing frames, after the introduction of digital publishing, increased the tension between the differentiated subunits, each upholding different frames. Rival frames manifest themselves in texts in the form of metaphors, exemplars, catchphrases, depictions, visual images to draw the attention of the audience in favor of the discourse they represent. These linguistic utterances and visual representations make frames more notable, vivid, 
memorable, impressive, and easily communicated. Moreover, frames couch argumentative media that justify and support causalities within and logical ground of a situation, event, or concept. As shown in Table 3, these devices can be enlisted as the consequences, appeals to principle, and roots (Creed, Langstraat, and Scully, 2002).

\subsection{At the Crossroad of Etatism and Liberal Economy: Turkey in the Post-Great Depression}

The first decade of the Republic of Turkey witnessed an economy-policy that aimed at laying the foundations of a private enterprise economy and creating a national bourgeoisie. The National Economic Congress, held in 1923 in İzmir, unequivocally determined the principals of this economic policy. In line with the notion of building a nation based on an entrepreneurial economy, these principals revolved around the establishment of both a property regime and an institutional infrastructure of a modern market (Buğra, 1994, p. 98). The congress adopted the principles of tariff protection of domestic industry and tariff exemptions for imported goods. In addition, the Encouragement of Industry Act of 1923 remained active throughout the decade (ibid. 99). As for agriculture, the state executed a series of initiatives to improve the welfare of small-medium peasantry. Among these efforts, the remarkable ones were the renouncing of the tithe, the expansion of arable lands, the improvement of logistics infrastructure, the promotion of new agricultural techniques, and the establishment of financial institutions (Pamuk, 2008, pp. 335-336).

Towards the end of the decade, however, the Turkish economy became vulnerable in terms of trade deficits as a result of the Great Depression of 1929, compelling government officials to adopt a restricted trade regime. Ahmad (1993, pp. 96-97) stated that the adverse effects of the Great Depression on peasantry and labor were disastrous, as prices dropped sharply. Inevitably, as of 1930, the Government promulgated a state-led economic development policy, also known as etatism, in the face of international conjuncture. Accordingly, the State took over the previously privatized state-monopolies and suspended, not officially but practically, the encouragement of the private sector. By doing so, the state held the ownership controls of key enterprises operating in the transportation, banking, and finance industries and tightened its control over markets and prices (Pamuk, 2000, 2017).

On the other hand, official state discourse was justifying the etatist policy as it would not hamper private entrepreneurial initiatives, but rather, aim to undertake commercial projects that were at the time strategically critical for national sovereignty and beyond the capacity of private enterprises (Lewis, 1961, p. 286). In this vein, the state set in motion two Industrial Master Plans (IMP) in 1934 and 1938, respectively. Especially the former plan located the State to a central position in textiles, iron-steel, glass, cement, and mining industries (Hale, 1980).

As a corollary of transition toward etatism, the state-led agricultural policy found itself a remarkable space in the agriculturalcooperative field. The law-maker enacted a series of cooperative Acts between 1929 and 1935, subordinating supposedly democratic cooperatives to the state-owned Ziraat Bank. Especially the Bank would strengthen its position in the agriculturalcooperative field as the omnipotent overarching organization on top of agricultural cooperatives. Explicitly, the \#2834 and \#2836 Acts of 1935 (T. C. Resmi Gazete, 2 October 1935, Issue: 3146) were granting such extensive power to the Ziraat Bank that, in the aftermath of their enactment, the Bank acquired the authority of deciding the founding locations of cooperatives, the extensive control and inspection rights over them, and the veto rights over the board elections and decisions. Moreover, the Bank became the primary financial sponsor of agricultural cooperatives and the training institution of cooperative personnel. In short, from 1929 onwards, agricultural cooperatives gradually became the extensions of the state as they cropped up, flourished, and survived under permanent custody, surveillance, and control of the state-owned Ziraat Bank.

\section{METHODOLOGY}

\subsection{Historical Case Study}

The perception about history in organization studies continued for long to be misguided that history was a craft-like domain where theory and methodology could take either little place at best or no place at all (Rowlinson, 2004, p. 301). Despite this misunderstanding, historical methods have proven their qualities as they open avenues for scholars to interpret organizational phenomena and help them to build/develop/refine their theories. Moreover, based on theoretical or historical sampling, "...historical studies are empirically oriented and emergent, opening the researcher to novel and unexpected findings and theories that cannot emerge using the traditional, deductive, hypothesis-testing methods of quantitative research" (Yates, 2014, p. 279).

Scholars have repeatedly addressed the necessity for the cross-fertilization between history and organization theory and documented the frequent interplay between them in different research programs (Kipping and Üsdiken, 2008, 2014; Üsdiken and Kieser, 2004). However, they urge the students of organization theory not to subordinate history to organization theory or vice versa while taking history seriously (Leblebici, 2014). To accomplish this balanced and robust partnership, according to Leblebici 
and Shah (2004), a given business history study has to be in accord while suggesting narrative explanations by locating sequential events onto a structured plot, avoiding the pointless chronological order of past events and situating a coherent theory. By doing so, as highlighted by Maclean and colleagues (2016), historically informed theoretical narratives prove valuable as long as they support theory development and satisfy historical veracity simultaneously. Accordingly, in this study, we have adopted the narration of a historical case with the potential of both making a theoretical contribution and illuminating a missing piece in Turkish cooperative history.

\subsection{Archival Data}

Unless a given research orientation aims theory testing or refinement (Kipping and Üsdiken, 2014), the scientific inquiry starts from a historiographical debate or the archival search. Following one of these two starting points, historical case study proceeds through searching for appropriate theory illuminating historiography or archives (Rowlinson and Hassard, 2013, p. 113). If taken the archival data as the head start, the historical discovery generally relies on the collected, sorted, organized, cataloged, and reserved texts and documents, which are the material representations of the collective memory (Ocasio, Mauskapf, \& Steele, 2015). In this respect, we have followed the procedure of hermeneutical discourse analysis suggested by Prasad and Mir (2002), which is also shown in Table 1. To start with, we have sorted the articles in the Journal of Türk Kooperatifçisi published between 1930 and 1933 inclusive. Drawing on this first Turkish cooperative periodical, we have read 214 articles, amounting to 966 pages. In addition to these archival documents, we have also read the literature on the socio-economic context of Turkey, especially the state's compulsory transition from liberal economic policy to etatism effective from the post-Great depression of 1929 . After completing the second stage, we have proceeded to the third stage of the textual interpretation.

Table 1: The Application of the Four-Stage Model of Hermeneutical Discourse Analysis (Adopted from Prasad and Mir (2002))

\begin{tabular}{|c|c|c|c|c|}
\hline & $\begin{array}{c}\text { Stage } 1 \\
\text { (Selection of texts) }\end{array}$ & $\begin{array}{c}\text { Stage } 2 \\
\text { (Context introduction) }\end{array}$ & $\begin{array}{c}\text { Stage } 3 \\
\text { (Completion of the } \\
\text { hermeneutical circle) }\end{array}$ & $\begin{array}{c}\text { Stage } 4 \\
\text { (Conceptual framing) }\end{array}$ \\
\hline $\begin{array}{l}\text { Republican } \\
\text { Period }\end{array}$ & $\begin{array}{l}\text { Selected periodical } \\
\text { (Türk Kooperatiçisi) }\end{array}$ & $\begin{array}{l}\text { The reading of the early } \\
\text { Republican era of Turkey } \\
\text { between (1923 - 1940) }\end{array}$ & $\begin{array}{c}\text { Social-historical \& } \\
\text { formal moments (see } \\
\text { Table 2) }\end{array}$ & $\begin{array}{c}\text { Shifts in prevalent macro } \\
\text { discourse and the failure } \\
\text { of the Liberal frame }\end{array}$ \\
\hline
\end{tabular}

\subsection{Interpretation and Narrative Construction}

Textual interpretation requires a systematic reading of the sources at hand, which in turn lend itself to a consistent understanding of the focal phenomenon. This kind of reading turns into a conversation among the context, text, and interpreter (Kerr, Robinson, \& Elliott, 2016). Building on the procedure suggested by (Phillips \& Brown, 1993), as summarized in Table 3, the conversation includes the understanding of the purpose of the text creation (intentional aspect), the interplay between various texts (in our case, this means a holistic view towards the articles in our data set) (referential aspect), and an integral understanding of the text and its context (contextual aspect). In what follows, the conversation turns towards the formal structure of the text. The formal aspect of a given text is twofold; (1) social conventions that the text follows and (2) the consistency of textual structure in terms of holistic and partial integrity (Phillips \& Brown, 1993, p. 1553-1554). Within this interpretation cycle, the interpreter iteratively swings back and forth between the text as a whole and its sub-texts (paragraphs, sentences, sections), its genre, and its context (Boland, Newman, and Pentland, 2010, p. 4). Finally, in the last stage, the researcher reviews his/her understandings from the conversation until then and yields his/her interpretations (Phillips \& Brown, 1993, p. 1554).

Following this procedure, we have interpreted the historical case of the Türk Kooperatifçisi and plotted our empirical evidence onto a storyline. Thus, in the following section, we elaborate on our narrative as to how a journal with a liberal worldview failed to resist to macro-level discursive change in early Republican Turkey.

Table 3: Hermeneutical Cycle (Cited from Phillips \& Brown, 1993)

\begin{tabular}{ll}
\hline \hline Characteristics & Description \\
\hline Intentional Aspect & $\begin{array}{l}\text { Texts are not natural occurrences, but intentional acts of some individual or } \\
\text { group. }\end{array}$ \\
Referential Aspect & $\begin{array}{l}\text { Texts are constructions that represent something, refer to something, or say Social-historical } \\
\text { something about something. }\end{array}$ \\
\hline
\end{tabular}




\begin{tabular}{llc}
\hline \hline Contextual Aspect & $\begin{array}{l}\text { The meaning of a text is inseparable from the social and historical context of } \\
\text { its production and reception. }\end{array}$ & Social-historical \\
$\begin{array}{l}\text { Conventional } \\
\text { Aspect }\end{array}$ & As meaningful constructs, texts follow conventions of various kinds. & Formal \\
Structural Aspect & $\begin{array}{l}\text { The meaningfulness of a text lies in the relation of the elements that make it } \\
\text { up. This relation is the text's structure. }\end{array}$ & Formal
\end{tabular}

\section{THE HISTORICAL NARRATIVE OF THE TÜRK KOOPERATIFÇISI}

\subsection{The Aydin Fig Producer Cooperative, 1913-1935}

Apart from the pseudo-cooperatives of the Ottoman Memleket Sandiks (Erçek and Soydemir, 2017) and the ephemeral consumption cooperatives in the Constitutional Ottoman era (Saka, 1962), the Aydın Fig Producer Cooperative (AFPC) was the first cooperative par excellence in Turkish cooperative history. Aligned with the contemporary Rochdale cooperatives of the UK, the AFPC was displaying most of the characteristics that a modern cooperative should have. Together with the abovementioned consumption cooperatives in the Constitutional Ottoman Empire, this promising cooperative movement emerged in a bottom-up fashion in the city of Aydın by the local fig producers in 1913 as a reaction to the afflicting exploitation of local producers by the fig exporting Trust, namely the Fig Packers (Birgen, 1930a). This Trust used to collect fig products from peasants at low prices employing the local merchants. In the face of the predatory attitude of the Trust, the peasantry, under the leadership of an intellectual, proactively established the first cooperative in 1913 and the Aydın Bank in 1914, respectively. Although these organizations did not legally have a cooperative status at those times due to the lack of corresponding legislative framework, they were displaying distinctive characteristics of a cooperative, including the democratic governance mechanisms, the prioritization of member interest over organizational ones, and the promotion of solidarity among member peasantry (Türk Kooperatifçisi, 1930).

\subsection{The journal of Türk Kooperatifçisi, 1930-1933}

After its reorganization with the advent of the Republican regime in 1923, this exemplary cooperative published a very original periodical, the Türk Kooperatifçisi. The journal was first revealed in March of 1930 and got published until April of 1933. Nazmi Topçuoğlu, who was the owner of the journal and the founder of the AFPC, used to write articles under the cover name of Kooperatifçi. His colleague and comrade, Muhittin Birgen, was the chief editor of the journal and undertook vast responsibilities about the journal. In the Türk Kooperatifçisi, Birgen was predominantly producing the liberal discourse accompanied by Topçuoğlu. The journal was ultimately reflecting the cooperative philosophy of these two men, who were passionately envisaging free cooperatives in a liberal economy and severely opposing against state-owned or state-governed cooperatives in an etatist economy. Ironically, the first publication of the journal coincided with the turbulent times of the post-Depression of 1929 in which the young Republic was on the verge of making a critical decision of whether pursuing a liberal and entrepreneurial economy or shifting toward the etatist economic policy.

Birgen was explicitly giving the prescription to overcome the adverse effects of the Great Depression in his writings early in 1930. Once, he stated that "... obviously, at the moment, Turkey is in a deep economic crisis emanating from the Depression. What is urgent now is to amend the articles of the Trade Law so that cooperatives become regulated in line with liberal cooperative notions" (Birgen, 1930a). Elsewhere, Birgen (1930b) was blaming communists as they had failed to prove their ideological claims over the world order and insistently stressing that Turkish decision-makers had to refrain from the supervision and coercion on cooperatives. According to Birgen (1930c), the current regulations were not allowing entrepreneurs to establish 'real cooperatives,' thus exposing these organizations to misconduct and corruption. He was stating that "...our Trade Act addresses only the 'one-member, one-vote' principle of Rochdale cooperatives. The rest of the twenty-five articles are circumstantial to the notion of cooperatives. They are far from addressing our problems." Moreover, he was also criticizing the first Agricultural Credit Cooperatives Act of 1924 (T. C. Resmi Gazete, 24 May 1924, Issue: 71) and ascribing the failure of the Act to the broad authority given to the state-owned Ziraat Bank over agricultural cooperatives (Birgen, 1930d).

At the turn of 1931, Birgen was summoned to participate in the first Agricultural Congress held in Ankara. While describing his impressions from this congress in his column, he did not hesitate to express his disappointment from the prevalent discourse on agricultural policy. He was complaining that "the spirit of this congress was reflecting great expectations from the State to carry out every initiative in the social and economic spheres of life. Not surprisingly, the socio-political administrative system, which has prevailed in the country for centuries, becomes an obstacle against the self-actualization and self-confidence of the populace, 
thus extinguishing individual initiatives from the outset and raising expectations from the state. On the one hand, pro-populists were not able to understand that state-led cooperatives would not serve their interests, on the other, the ardent advocates of etatism were not aware of the fact that these so-called cooperatives would destroy the idea of cooperatives in the first place. The dominant view revolves around the adoption of the subordination of cooperatives to the state. They cannot even understand that building walls around Turkey would cause nothing but isolation from the external world" (Birgen, 1931a). Birgen (1931b) was underscoring elsewhere that "...there is an emerging danger at the horizon that a bureaucratic intelligentsia is now advocating a top-down organization of cooperatives under the state surveillance. We recommend them to stay aloof from cooperatives and seek alternative organizations to realize their agenda."

This hot debate over the structure and the normative ground of Turkish cooperatives escalated and turned into a discursive battle between Muhittin Birgen, the resolute advocate of liberal cooperatives, and Suphi Nuri, an ardent pro-etatism author, who used

Table 3: Competing Primary Frames in the Texts

\begin{tabular}{|c|c|c|c|}
\hline & & Etatist Frame & Liberal Frame \\
\hline \multirow{7}{*}{$\begin{array}{l}\text { Idea elements } \\
\text { embedded in } \\
\text { texts }\end{array}$} & Metaphors & $\begin{array}{l}\text { Cooperative is a department of the } \\
\text { state (quoted from Nuri in Birgen, } \\
\text { 1931c) }\end{array}$ & $\begin{array}{l}\text { The state does not establish cooperatives; } \\
\text { instead, she is supposed to support them } \\
\text { in terms of technical expertise and financial } \\
\text { aids (Topçuoğlu, 1931). }\end{array}$ \\
\hline & Exemplars & $\begin{array}{l}\text { Positive: The Turkish Republic has given } \\
\text { rise to cooperatives. } \\
\text { Negative: Cooperatives, which deprive } \\
\text { of state leadership, are destined to fail. }\end{array}$ & $\begin{array}{l}\text { Positive: The cooperative movement is } \\
\text { now in the emerging phase. There are } \\
\text { exemplary and functional cooperatives in } \\
\text { Turkey next to bad examples. } \\
\text { Negative: As obviously proved by the Act of } \\
\text { 1924, the Turkish experiment on state-led } \\
\text { agricultural cooperatives failed. }\end{array}$ \\
\hline & Catchphrases & One for all, all for one. & $\begin{array}{l}\text { The more liberal the cooperatives, the } \\
\text { higher the agricultural production (Birgen, } \\
\text { 1930a) }\end{array}$ \\
\hline & Depictions & $\begin{array}{l}\text { Cooperatives are the offspring of the } \\
\text { Republic. }\end{array}$ & $\begin{array}{l}\text { The doors of cooperatives are open to } \\
\text { everyone. }\end{array}$ \\
\hline & Roots & $\begin{array}{l}\text { Cooperatives are levers for our export } \\
\text { figures. }\end{array}$ & $\begin{array}{l}\text { Cooperatives contribute to the growth of } \\
\text { the rural economy. }\end{array}$ \\
\hline & Consequences & $\begin{array}{l}\text { The more state involvement in } \\
\text { cooperative affairs, the more } \\
\text { developed Turkey. }\end{array}$ & $\begin{array}{l}\text { Cooperatives serve to the peasantry as } \\
\text { long as they align with the original } \\
\text { cooperative values. }\end{array}$ \\
\hline & Appeals to Principle & $\begin{array}{l}\text { State custody financially and } \\
\text { administratively elevates cooperatives. }\end{array}$ & $\begin{array}{l}\text { The fundamentals of cooperatives are } \\
\text { cooperation, commitment, altruism, and } \\
\text { the like. }\end{array}$ \\
\hline \multirow{3}{*}{$\begin{array}{l}\text { Functions of } \\
\text { Frames }\end{array}$} & $\begin{array}{l}\text { Punctuation: What } \\
\text { is the problem? }\end{array}$ & $\begin{array}{l}\text { The problem is that Turkish villager } \\
\text { does not have intellectual and financial } \\
\text { capital. Turkish villager is not ready to } \\
\text { initiate an enterprise on his own. }\end{array}$ & $\begin{array}{l}\text { The state custody over cooperatives } \\
\text { violates the ideal of the cooperative. }\end{array}$ \\
\hline & $\begin{array}{l}\text { Elaboration: Who is } \\
\text { responsible? What } \\
\text { outcomes can be } \\
\text { achieved with(out) } \\
\text { interventions? }\end{array}$ & $\begin{array}{l}\text { The state is responsible for carrying out } \\
\text { what the Turkish citizen is incapable of } \\
\text { doing. By so doing, she guarantees the } \\
\text { desired ends in rural life. }\end{array}$ & $\begin{array}{l}\text { Under the guidance of cooperative } \\
\text { pioneers and state-help in terms of } \\
\text { financial aid and technical expertise, the } \\
\text { peasantry should establish and own their } \\
\text { cooperatives. }\end{array}$ \\
\hline & $\begin{array}{l}\text { Motivation: What } \\
\text { action should be } \\
\text { taken? }\end{array}$ & $\begin{array}{l}\text { The state has to establish and organize } \\
\text { cooperatives on behalf of the } \\
\text { peasantry. }\end{array}$ & $\begin{array}{l}\text { Peasantry needs to be wary of their } \\
\text { interests. }\end{array}$ \\
\hline
\end{tabular}

to publish his articles in the state-supported journal, namely, 'Kooperatifçilik.' Birgen used to accuse his counterpart of ruining the ideal of cooperative as he was envisaging state-led cooperatives. Nuri was criticizing the naivety of Birgen's liberal ideas, which, according to him, did not apply to the Turkish setting at that time. The author avowedly (Birgen, 1931c) expressed his 
thoughts regarding the state-cooperative relationship as follows; “...cooperative is a department of the state. Under the custody and surveillance of the state, this department carries out initiatives that people fail to do. The state will establish a cooperative bank. The Institute of Cooperatives will open schools, publish materials, and engage in propaganda to influence the people." In his response, Birgen was sincerely declaring the absurdity of these insights and boldly accusing the state bureaucracy of acting like aristocracy with a Jacobin outlook. He went on to state that cooperative belongs to neither the state nor a particular political party; instead, their property and administrative rights belong only to their members. In his response, Nuri was stating that "...we, Turks, have been statist since our first existence in history. This is our nature. As the Turkish nation, we have always taken instructions from and become motivated by the state in our political, economic, and social life. This is who we are and will be" (Nuri, 1931). Birgen (1931d) retaliated that "...whomever advocates etatism cannot be pro-cooperatives simultaneously. Cooperatives are democratic and republican. Cooperatives respect the state; however, they cannot be a state department. As opposed to your argument, Turkish cooperatives have not failed yet due to a lack of state intervention. Contrarily, this is an emerging movement."

In a nutshell, the journal of Türk Kooperatifçisi advocated, during its short life span, the liberal cooperatives modeled after the British Rochdale cooperatives (see Muhittin's articles on Rochdale Pioneers in issues between 1 and 10). The Rochdale principles were portrayed as the gold standard in terms of the rules and norms it posited, thus determining the necessary conditions for an organization to be a cooperative. In another article by Birgen (1931e), he was addressing directly to the Minister of Economics, Mustafa Şeref, and markedly highlighting that "cooperative is nothing but Rochdale Principles. No more, no less." Throughout the issues of the journal, a vast number of articles repeatedly addressed the British cooperatives and the International Cooperative Alliance (ICA) founded in the UK and called for the avoidance of state hegemony. However, it should be recalled that actually, even Birgen was aware of the fact that Turkish cooperatives were needing help. The liberals were opposed to sovereign authority over cooperatives but welcomed the state support in the form of a facilitative regulatory framework, subsidies, and exemptions.

Under the changing circumstances in favor of etatist policies, however, agricultural cooperatives turned into state apparatuses, and finally, the AFPC had to merge with the state-led agricultural sales cooperatives in the aftermath of the new regulations in 1935. Correspondingly, the journal of Türk Kooperatifçisi ceased its publishing in 1933, heralding the beginning of a new etatist era.

\section{DISCUSSION}

"There are cooperatives around the world; however, none of them is under custody by a central bank in the capital city or its agencies in cities or villages. Truth to be told, elsewhere, the cooperatives have been established by state similar to our case. Tunisia, Algeria, and India are epitomes of this compulsory introduction. Nevertheless, even in these contexts, the states showed respect to the notions and values of cooperatives and strove to design these organizations accordingly" (Koyuncu, 1945, pp. 1415). As discussed, the above quote was a confession that came long after the purposeful configuration of agricultural cooperatives as state extensions. Initial arrangements by the Act of 1929 became not only ossified but also upgraded in favor of the Ziraat Bank after the enactment of the Act of 1935 and following complementary regulations. In other words, at the end of this period, the process of turning agricultural cooperatives into state departments completed so that they could serve the ideological agenda of the state along with peasantry interests (Soydemir and Erçek, 2019). Nevertheless, amid these changes, there was an outlier organization that diverges from the regular pattern of contemporary cooperatives, the AFPC.

The AFPC was a progressive organization far ahead of its spatio-temporal context. One of the significant indicators of its distinctiveness was the cooperative's specific interest in current affairs in the international cooperative field. It was the first and for a long time would be the only Turkish cooperative that became a member of the ICA. Moreover, the cooperative used to have a closed relationship with the British Cooperative Wholesale Society. Taken together, obviously, the decision-makers in AFPC turned their direction toward the Western cooperatives and took them as the anchor organizational form while designing their cooperative. The second indicator, also equally important with the first one, is the discourse produced by the cooperative's official periodical. By all means, the journal was producing and disseminating the liberal discourse from the first issue until the last issue; however, during the inevitable transition to etatist economy policies, the journal ceased publication. Although the closure article by Birgen (1933) was ascribing the termination of the journal to several reasons, notably the failure of the journal coincided with the rise of etatist discourse and policies in the country. Not surprisingly, six months later, the quasi-official state medium of the Karınca Journal would start its publication and advocate the state ideology in its pages (Soydemir and Erçek, 2019).

Our historical anecdote unveils an underemphasized fact by cooperative historians in Turkey. As opposed to the general view, the cooperative discourse in the agricultural field was fragmented into two contradictory and contesting discourses. The discursive struggle became manifested as liberal versus etatist, each of which had its advocates with their communication media. The journal Türk Kooperatifçisi was the flagship of the liberal discourse to design cooperatives based on Rochdale principles. The liberals had 
such a strong faith in independent cooperatives and grave concerns about state-led cooperatives that they used every discursive device available, especially by putting cooperatives in a liberal framework. Conveyed through articles, these efforts included bad examples of state-led cooperatives, catchphrases, i.e., divided we fall, united we stand, or metaphors such as the Russian cooperatives swallowed by the communist regime in the USSR.

Moreover, the liberals frequently addressed the Rochdale principles as the roots of cooperative notion, envisaged the positive outcomes of liberal cooperatives, and demonized the state bureaucracy for killing the spirit of cooperatives. Thus, our first contribution is to the history of Turkish cooperatives. We have revealed an overlooked fact that there was a plurality in the discursive arena in the case of agricultural cooperatives during the transition toward etatism at the macro level.

This transition brings about the question of whether the macro-level shift precipitated the defeat of the liberal discourse. To answer this quarrel, we elaborated on both the pre- and pro-Great Depression in Turkey. As discussed elsewhere, until the depression, the young Republic targeted at establishing a liberal economy based on free markets and private entrepreneurship. In this respect, the state expected the peasantry to establish their cooperatives by themselves. However, historical data yield no record of agricultural cooperatives between 1924 and 1929 except the AFPC. The advent of the Depression, however, opened space for debate over the extent of the state intervention to cooperatives. Until the sedimentation of etatism in the agriculturalcooperative field in 1935, this forum for liberal/etatist debate remained open for four years between 1929 and 1933 . Thus, as the left foot follows the right, the shift in discourse ensued the state polity at the macro level. However, the transition from liberal economic policy to etatism did not lead to an instant change in discourse; instead, it triggered a discursive struggle. Nevertheless, the finalization of the transition also shut the doors for the liberal discourse. Thus, our second contribution is to discourse literature. We have provided historical evidence that despite its sovereign power, the state does not necessarily silence opposing discourse right of the bat. Instead, it may open spaces for alternative voices.

\section{CONCLUSION}

The cooperatives in Turkey are today positioned as non-governmental organizations between the state and the people (Tekin, 2015). However, while their first introduction, they were conceptualized as state apparatuses, and this was so especially in the agricultural field. Given the fact that cooperatives are amenable to macro-level changes in the Turkish setting, the historical evolution of Turkish cooperatives gains prominence to understand the future path they might follow. In this vein, this study shows that before extreme state involvement, there was a possibility for the configuration of liberal agricultural cooperatives in Turkey. In this respect, the performance of the AFPC was exemplary; however, despite all discursive efforts, the liberal discourse was destined to erode in the face of rising statist policies. Nevertheless, one should recall that even a radical change like in our historical case may open new avenues for fruitful intellectual debates over the future of cooperatives.

\section{REFERENCES}

Ahmad, F. (1993). The making of modern turkey. London: Routledge.

Aschhoff, G. (1982). The banking principles of Hermann Schulze-Delitzsch and Friedrich Wilhelm Raiffeisen. In W. Engels, \& H. Pohl, German yearbook on business history 1982 (pp. 19-42). Cologne: Springer-Verlag.

Birgen, M. (1930a). İktisat buhranı ile mücadele programı [The economic program against the Depression]. Türk Kooperatifçisi(2), 1-9.

Birgen, M. (1930b). Dünyanın derdi bizim derdimiz [The global problem is our problem]. Türk Kooperatifçisi(3), 1-5.

Birgen, M. (1930c). Türkiye'de kooperatif hukukiyatı [The cooperative law in Turkey]. Türk Kooperatifçisi(5), 1-5.

Birgen, M. (1930d). Türkiye'de zirai itibar meselesi [The issue of the agricultural credits in Turkey]. Türk Kooperatifçisi(5), 20-25.

Birgen, M. (1931a). 1. ziraat kongresi [The first agricultural congress]. Türk Kooperatifçisi(11), 1-7.

Birgen, M. (1931b). Kooperatif rejiler. Türk Kooperatifçisi(13), 1-14.

Birgen, M. (1931c). Kooperatifleşme veya kooperatifleştirme [Cooperatives or psuedo-cooperatives]. Türk Kooperatifçisi(15-16), 1-11.

Birgen, M. (1931d). Suphi Nuri Bey'e cevabım [My response to Suphi Nuri Bey]. Türk Kooperatifçisi(19-20), 11-16.

Birgen, M. (1931e). Iktisat vekili muhterem mustafa şeref beyefendiye [To Mustafa Şeref, the Minister of Economics]. Türk Kooperatifçisi(12), 17.

Birgen, M. (1933). Kariyelerimize [To our readers]. Türk Kooperatifçisi(32), 24. 
Boland, R. J., Newman, M., \& Pentland, 2. (2010). Hermeneutical exegesis in information systems design and use. Information and Organization, 20(1), 1-20.

Buğra, A. (1994). State and business in modern turkey: A comparative study. Albany: State University of New York.

Cornelissen, J. P., \& Werner, M. D. (2014). Putting framing in perspective: A review of framing and frame analysis across the management and organizational literature. Academy of Management Annals, 8(1), 181-235.

Creed, W. E., Langstraat, \& Scully, M. (2002). A picture of the frame: Frame analysis as technique and as politics. Organizational Research Methods, 5(1), 34-55.

Erçek, M., \& Soydemir, C. O. (2017). The emergence of cooperatives as organizational forms in Turkish history, 1864-1938. Academy of Management Proceedings. doi:https://doi.org/10.5465/AMBPP.2017.17450abstract

Fairbairn, B. (2017). Raiffeisen as social innovator. Annals of Public and Cooperative Economics, 425-448.

Fairclough, N. (1989). Language and power. New York: Longman Inc.

Fairclough, N. (2005). Peripheral vision: Discourse analysis in organization studies: The case for critical realism. Organization Studies, 915-939.

Farr, I. (2007). Farmers' cooperatives in Bavaria, 1880-1914: 'State-help 'and 'self-help' in imperial Germany. Rural History, 18(2), 163-182.

Genç, M. (2000). Osmanlı imparatorluğunda devlet ve ekonomi [State and Economy at the Ottoman Empire]. Istanbul: Ötüken Neşriyat.

Gilbert, C. G. (2006). Change in the presence of residual fit: Can competing frames coexist? Organization Science, 17(1), 150-167.

Goffman, E. (1974). Frame analysis: An essay on the organization of experience. Boston: North Eastern University Press.

Gopinath, C., \& Prasad, A. (2012). Toward a critical framework for understanding MNE operations: Revisiting Coca-Cola's exit from India. Organization, 212-232.

Grant, D., Hardy, C., Oswick, C., \& Putnam, L. L. (2004). Introduction: Organizational discourse: Exploring the field. In D. Grant, C. Hardy, C. Oswick, \& L. L. Putnam, The sage handbook of organization discourse (pp. 1-36). London: Sage.

Guinnane, T. W. (1997). Regional organizations in the German cooperative banking system in the late 19th century. Research in Economics, 51, 251-274.

Guinnane, T. W. (2012). State support for the German cooperative movement, 1860-1914. Central European History, 45, $208-232$.

Gurses, K., \& Ozcan, P. (2015). Entrepreneurship in regulated markets: Framing contests and collective action to introduce pay tv in US. Academy of Management Journal, 58(6), 1709-1739.

Hale, W. (1980). Ideology and economic development in Turkey 1930-1945. British Society for Middle Eastern Studies. Bulletin, 7(2), 100-117.

Hargadon, A. B., \& Douglas, Y. (2001). When innovations meet institutions: Edison and the design of the electric light. Administrative Science Quarterly, 476-501.

Hazar, N. (1990). Kooperatiff̧ilik tarihi [The history of cooperatives] (3rd ed.). Ankara: Tarım Kredi Kooperatifleri Yardımlaşma Birliği Yayınları.

International Co-operative Alliance. $(2019,12$ 22). Co-operative identity, values \& principles. Retrieved from Coop International Co-operative Alliance: https://ica.coop/en/whats-co-op/co-operative-identity-values-principles

Jepperson, R. L. (2002). Political modernities: Disentangling two underlying dimensions of institutional differentiation. Sociological Theory, 20(1), 61-85.

Kerr, R., Robinson, S. K., \& Elliott, C. (2016). Modernism, postmodernism, and corporate power: Historicizing the architectural typology of the corporate campus. Management and Organizational History, 11(2), 123-146.

Kipping, M., \& Üsdiken, B. (2008). Business history and management studies. In G. Jones, \& J. Zeitlin, The Oxford Handbook of Business History (pp. 96-119). Oxford: Oxford University Press.

Kipping, M., \& Üsdiken, B. (2014). History in organization and management theory: More than meets the eye. Academy of Management Annals, $8(1), 535-588$.

Kipping, M., Wadhwani, R. D., \& Bucheli, M. (2014). Analyzing and interpreting historical sources: A basic methodology. In M. Bucheli, \& R. D. Wadhwani, Organizations in time: History, theory, methods (pp. 306-329). Oxford: Oxford University Press.

Koyuncu, A. (1945). Kooperatiflerin birleşmesi [The merge of cooperatives]. Karınca(101), 10-16.

Kyratsis, Y., Atun, R., Phillips, N., Tracey, P., \& George, G. (2017). Health systems in transition: Professional identity work in the context of shifting institutional logics. Academy of Management Journal, 60(2), 610-641. 
Leblebici, H. (2014). Organizational research in history and organization theory in the first decade of the 21st century: Potential for a transdisciplinary convergence. In M. Bucheli, \& R. D. Wadhwani, Organizations in time. History, theory, methods (pp. 56-99). Oxford: Oxford University Press.

Leblebici, H., \& Shah, N. (2004). The birth, transformation and regeneration of business incubators as new organisational forms: Understanding the interplay between organisational history and organisational theory. Business History, 46(3), 353-380.

Leibel, E., Hallett, T., \& Bechky, B. A. (2018). Meaning at the source: The dynamics of field formation in institutional research. Academy of Management Annals, 12(1), 154-177.

Lewis, B. (1961). The emergence of modern Turkey. London: Oxford University Press.

Maclean, M., Harvey, C., \& Clegg, S. R. (2016). Conceptualizing historical organization studies. Academy of Management Review, 41(4), 609-632.

McLaughlin, E., \& Sharp, P. (2019). Competition between organisational forms in Danish and Irish dairying around the turn of the twentieth century. Business History. doi:https://doi.org/10.1080/00076791.2019.1575366

Murphy, M. E. (1946). Centenary of the British Coopeartive Movement. Journal of Marketing, 270-278.

Navis, C., \& Glynn, M. A. (2010). How new market categories emerge: Temporal dynamics of legitimacy, identity, and entrepreneurship in satellite radio, 1990-2005. Administrative Science Quarterly, 55(3), 439-471.

Nuri, S. (1931). Suphi Nuri Bey'in cevabı [The response of Suphi Nuri Bey]. Türk Kooperatifçisi(19-20), 5-10.

Ocasio, W., Mauskapf, M., \& Steele, C. W. (2015). History, society, and institutions: The role of collective memory in the emergence and evolution of societal logics. Academy of Management Review, 41(4), 676-699.

Pamuk, Ş. (2000). Intervention during the great depression. In Ş. Pamuk, \& J. G. Williamson, The mediterranean response to globalization before 1950 (pp. 321-339). London : Routledge.

Pamuk, Ş. (2008). Economic change in twentieth-century turkey: Is the glass more than half full? In R. Kasaba, The cambridge history of turkey: Turkey in the modern world (Vol. IV, pp. 266-300). Cambridge: Cambridge University Press.

Pamuk, Ş. (2017). Türkiye'nin 200 yıllık iktisadi tarihi [Turkey's 200 years of economic history] (7th ed.). Istanbul: Türkiye İş Bankası Kültür Yayınları.

Phillips, N., \& Brown, J. L. (1993). Analyzing communication in and around organizations: A critical hermeneutic approach. Academy of Management Journal, 36(6), 1547-1576.

Phillips, N., \& Oswick, C. (2012). Organizational discourse: Domains, debates, and directions. The Academy of Management Annals, $435-481$.

Prasad, A., \& Mir, R. (2002). Digging deep for meaning: A critical hermeneutic analysis of CEO letters to shareholders in the oil industry. Journal of Business Communication, 92-116.

Rao, H. (1998). Caveat emptor: The construction of nonprofit consumer watchdog organizations. American Journal of Sociology, 103(4), 912-961.

Rao, H., \& Greve, H. R. (2017). Disasters and community resilience: Spanish flu and the formation of retail cooperatives in Norway. Academy of Management Journal, 61(1), 2-25.

Rao, H., \& Singh, J. V. (2001). The construction of new paths: Institution-building activity in the early automobile and biotech industries. In R. Garud, \& P. Karnøe, Path Dependence and Creation (pp. 243-267). London: Erlbaum.

Rowlinson, M. (2004). Historical analysis of company documentation. In C. Cassell, \& G. Symon, Qualitative methods in organizational (pp. 301311). London: Sage.

Rowlinson, M., \& Hassard, J. S. (2013). Historical neo-institutionalism or neo-institutionalist history? Historical research in management and organization studies. Management and Organizational History, 8(2), 111-126.

Saka, R. (1962). Meşrutiyet Türkiyesi kooperatifçiliği [Cooperatives in the Constitutional Turkey]. Karınca(304), 12-18.

Schneiberg, M. (2013). Movements as political conditions for diffusion: Anti-Corporate movements and the spread of cooperative forms in American capitalism. Organization Studies, 34(5-6), 653-682.

Soydemir, C. O., \& Erçek, M. (2019). Self-help or vassal? State ideology and discursive legitimization of Turkish cooperatives, $1934-1960$. Academy of Management Proceedings. doi:https://doi.org/10.5465/AMBPP.2019.18304abstract

T. C. Resmi Gazete. I'tibari zirâi birliği kanunu. 24 May 1924. Issue: 71, Başbakanlık Basımevi, Ankara.

T. C. Resmi Gazete, Tarım kredi kooperatifleri kanunu. 2 October 1935. Issue: 3146, Başbakanlık Basımevi, Ankara. 
Tekin, H. H. (2015). Devlet ve birey arasında bir güç alanı olarak kooperatifler [Cooperatives as a power field between the state and individual]. Üçüncü Sektör Sosyal Ekonomi, 50(2), 135-151.

Topçuoğlu, N. (1931). Kooperatifler nasıl çoğalır? [How do cooperatives spread?]. Türk Kooperatifçisi(12), 7-11.

Tracey, P., Dalpiaz, E., \& Phillips, N. (2018). Fish out of water: Translation, legitimation, and new venture creation. Academy of Management Journal, 61(5), 1627-1666.

Trampusch, C., \& Spies, D. C. (2014). Agricultural interests and the origins of capitalism: A parallel comparative history of Germany, Denmark, New Zealand, and the USA. New Political Economy, 19(6), 918-942.

Türk Kooperatifçisi. (1930). Türkiye'de zirai îtibar meselesi [The issue of agricultural credit in Turkey]. Türk Kooperatifçisi(4), 19-22.

Üsdiken, B., \& Kieser, A. (2004). Introduction: History in organisation studies. Business History, 46(3), 321-330.

Werner, M. D., \& Cornelissen, J. P. (2014). Framing the change: Switching and blending frames and their role in instigating institutional change. Organization Studies, 35(10), 1449-1472.

Yates, J. (2014). Understanding historical methods in organization studies. In M. Bucheli, \& R. D. Wadhwani, Organizations in time: History, theory, methods (pp. 265-283). Oxford: Oxford University Press.

York, J. G., Hargrave, T. J., \& Pacheco, D. F. (2016). Converging winds: Logic hybridization in the colorado wind energy field. Academy of Management Journal, 59(2), 579-610. 